\title{
Penguatan Nilai-Nilai Religius di Perguruan Tinggi
}

\author{
${ }^{1}$ Yulianti, ${ }^{2}$ Stephani Raihana Hamdan, ${ }^{3}$ Dian Widya Putri \\ 1,3Fakultas Ilmu Komunikasi, Universitas Islam Bandung Jl. Taman Sari No 1 Bandung 40116 \\ ${ }^{2}$ FakultasPsikologiUniversitas Islam Bandung Jl. Taman Sari No 1 Bandung40116 \\ E-mail: 1yulianti@unisba.ac.id; ${ }^{2}$ stephanie.raihana@gmail.com; ${ }^{3}$ dianwidyaputri@unisba.ac.id
}

\begin{abstract}
Abstrak: Globalisasi dan perkembangan teknologi membawa dampak pada persaingan keunggulan dalam segala aspek kehidupan, tak terkecuali dalam bidang pendidikan. Pendidikan menjadi dasar utama strategi suatu bangsa untuk bangkit dari keterpurukan. Unisba merupakan salah satu pilihan bagi para orang tua yang tidak hanya mempertimbangkan kualitas, namun juga memprioritaskan penerapan nilai keagamaan yang baik. Sejatinya, aksioma dari output mahasiswa yang baik di masa depan, erat kaitanya dengan nilai-nilai yang baik, keahlian-kehalian yang baik, serta sikap yang baik. Tujuan akhir Pendidikan Islam adalah munculnya pembinaan akhlak, sehingga tepat untuk memberikan penguatan nilai-nilai religius di Fikom Unisba. Penelitian ini terkait dengan upaya penguatan nilai religius yang dilakukan Fikom Unisba yang menggunakan pendekatan kualitatif. Subjek penelitian ini adalah Dr. O. Hasbiansyah, Drs., M.Si. selaku Dekan Fakultas Ilmu Komunikasi Universitas Islam Bandung. Pengauatan nilai-nilai religius ditanamkan Fakultas Ilmu Komunikasi Universitas Islam Bandung di setiap lini kehidupannya. Mulai dari kurikulum, sumber daya manusia (tenaga pendidik, tenaga kependidikan, dan mahasiswa), maupun lingkungan kerja (setting). Menjadikan nilai-nilai islami sebagai yang tak terpisahkan dengan pekerjaan dan pelayanan. Kesemuanya terintegrasi di dalam satu sistem, demi terciptanya penguatan nilai yang menjadi tujuan bersama.
\end{abstract}

Kata kunci: penguatan, nilai religius, perguruan tinggi

\begin{abstract}
Globalization and technological development has impact on competition for the excellence in all aspects of life, including in the field of education. Education is the main basis of a nation's strategy to rise from adversity. Bandung Islamic University (Unisba) is one option for parents who not only consider about quality, but also prioritize the application of good religious values. Indeed, the axiom of good student output in the future is closely related to good values, good skills and a good attitude. The ultimate goal of Islamic Education is the emergence of moral guidance, so that it is appropriate to strengthen religious values in Fikom Unisba. This research is related to the efforts to strengthen the religious values carried out by the Faculty of Communication Sciences of Unisba which is use a qualitative approach. The subject of this study was Dr. O. Hasbiansyah as the Dean of the Faculty of Communication, Unisba. Management of religious values instilled in the Faculty of Communication in every aspects. Starting from the curriculum, human resources (lecturer, education staff, and students), as well as the work environment (setting). This is makes Islamic values inseparable from work and service. All of them are integrated in one system, in order to create strenghtening of value as the common goal.
\end{abstract}

Keywords: strengthening, religious value, college 


\section{PENDAHULUAN}

Globalisasi dan perkembangan teknologi membawa dampak pada persaingan keunggulan dalam segala aspek kehidupan, tak terkecuali dalam bidang pendidikan. Dampak globalisasi dalam pendidikan semakin terasa. Salah satunya adalah peningkatan kualitas pendidik dan pendidikan dengan berbagai referensi pembelajaran yang ada. Kesadaran orang tua ihwal pentingnya pendidikan yang berkualitas bagi putraputrinya semakin meningkat, perguruan tinggi yang berkualitas dan mempunyai nilai lebih semakin banyak bermunculan dan semakin banyak dicari. Di dalam pemilihan perguruan tinggi para orang tua tidak hanya mempertimbangkan kualitas, namun juga memprioritaskan penerapan nilai keagamaan yang baik, dan Universitas Islam Bandung merupakan salah satu pilihannya.

Disepakati bersama bahwa aksioma dari output mahasiswa yang baik di masa depan, erat kaitanya dengan nilai-nilai yang baik, keahlian-kehalian yang baik, serta sikap yang baik. Pendidikan menjadi dasar utama strategi suatu bangsa untuk bangkit dari keterpurukan. Oleh karena itu, menghadirkan spiritualitas dalam pendidikan akan memberi makna besar terhadap kemajuan kehidupan bangsa (Agustian, 2008: 15). Internalisasi nilai-nilai pendidikan dalam proses pembelajaran merupakan bagian penting yang perlu dikembangkan agar ilmu yang diperoleh peserta didik dalam hal ini mahasiswa, menjadi lebih bernilai dan bermakna.

Pendidikan merupakan corong yang membangun generasi baru yang lebih baik. Sebagai alternatif yang bersifat preventif, pendidikan diharapkan dapat mengembangkan kualitas peserta didiknya (mahasiswa) sehingga dapat memperkecil dan mengurangi terjadinya masalah degradasi moral. Kendati demikian, diakui bahwa hasil dari pendidikan tidaklah instan, banyak terjadi proses di dalamnya, dan diyakini benar memiliki pengaruh yang kuat untuk masa yang akan datang.

Kemajuan ilmu pengetahuan dan teknologi menunjukkan adanya konsekuensi logis pada terciptanya kondisi yang mencerminkan kemerosotan akhlak (dekadensi moral) (Daulay, 2012:141). Nilai-nilai spiritualitas agama menjadi momok dalam kehidupan masyarakat sehingga pada akhirnya mereka menuntut agar urusan agama dipisahkan dengan urusan akhirat. Dengan kata lain, meningkatnya kemajuan teknologi, berimbas pula pada pergerakan masyarakat yang semakin sekular.

Menjawab tantangan tersebut, Universitas Islam Bandung (Unisba) sebagai perguruan tinggi swasta berlabelkan Islam, senantiasa membentengi setiap lini kehidupannya dengan nilai-nilai religius. Baik itu tercermin dari kurikulum, penyaringan sumber daya manusia (tenaga pendidik, tenaga kependidikan, dan mahasiswa), lingkungan kerja (setting), dll.

Fakultas Ilmu Komunikasi (Fikom) sebagai salah satu fakultas yang ada di Unisba, mempunyai tantangannya tersendiri. Pasalnya, dari temuan awal yang dilakukan peneliti, fakultas ini mendapat pelabelan negatif terkait mahasiswanya. Gaya pakaian yang tidak sesuai dengan nilai-nilai Islam, sikap dan perilaku yang tidak sesuai dengan etika profesi dan etika Islam, serta kurangnya kemampuan untuk dapat berkomunikasi yang baik. Penguatan nilai-nilai religius muncul dipicu oleh stigma yang mengatakan bahwa mahasiswa Fikom Unisba adalah mahasiswa "gaul", "kritis" dengan konotasi yang negatif. (baca: nyeleneh dalam gaya fashion dan suka protes), sehingga jika terjadi peristiwa (demontrasi) yang melibatkan mahasiswa, opini secara langsung tergiring, "pasti mahasiswa Fikom!" 
Di sisi lain, indikator sebuah lembaga pendidikan dikatakan maju tidak hanya melihat pada tinggi rendahnya kuantitas mahasiswa sebagai peserta didik, tetapi juga pada kualitas kompetensi yang dimiliki para peserta didik dan lulusannya, baik dilihat dari nilai akademik maupun dari sisi prestasi non-akademik termasuk sikap dan perilaku peserta didik yang baik dan berkarakter mulia. Fikom Unisba sendiri, telah memenuhi aspek kuantitas peserta didiknya. Berdasarkan data yang peneliti peroleh dari Pusat Pengolahan Data (Puslahta) tahun akademik 2017, jumlah pendafar untuk Fikom Unisba yang dibuka sebanyak 3 (tiga) gelombang, terkumpul sebanyak 1.220 pendaftar. Jumlah ini menempati urutan kedua setelah Fakultas Kedokteran, yakni sebanyak 2.241 pendaftar. Jumlah pendaftar untuk Fakultas Ilmu Komunikasi meningkat dari tahun sebelumnya yakni sebanyak 1.106 pendaftar. Dilihat dari aspek kualitas kompetensi mahasiswa dan lulusannya juga sudah semakin memadai, mahasiswa digenjot dengan penguatan nilai-nilai religius khas Fikom Unisba, yakni BTAQ menjelang sidang komprehensif dan sidang skripsi oleh dosen-dosen internal Fikom sendiri. Ditambah lagi, Fikom juga merupakan pelopor berdirinya Lembaga Sertifikasi Profesi Unisba dalam menghadapi Masyarakat Ekonomi ASEAN (MEA).

Meskipun di lain pihak, sikap dan perilaku peserta didik, dalam hal ini mahasiswa Fikom Unisba, masih perlu banyak pembinaan lagi. Hubungan antara dosen dan mahasiswa yang terlalu cair, kadang mengaburkan esensi kedudukan antara pendidik dan peserta didik (dosen dan mahasiswa), saking cairnya, mahasiswa kurang bisa membatasi diri dan terkesan berani terhadap dosen. Namun demikian, dalam suatu institusi pendidikan masalah nilai-nilai islami tentu saja bukan menjadi hal yang penting bagi mahasiswa saja, pihak penyelenggara dalam hal ini dosen, tenaga kependidikan dan karyawan lainnya juga harus menjadikan nilai-nilai islami menjadi bagian dari segala hal yang terkait dengan pekerjaan dan pelayanan mereka. Kesemuanya terintegrasi di dalam satu sistem, demi terciptanya penguatan nilai yang menjadi tujuan bersama.

Di antara empat tujuan akhir pendidikanIslam, salah satukomponennya terkait dengan munculnya pembinaan akhlak, sehingga tepat untuk memberikan penguatan nilai-nilai religius di Fikom Unisba. Hal tersebut didukung pula oleh pernyataan Gray dalam Character Education in Schools(2010) yang mencoba untuk membuktikan bahwa pendidikan dapat digunakan sebagai alat yang terbukti secara signifikan mengurangi terjadi degradasi moral.

Dari sisi inilah maka dirasa perlu untuk melakukan penguatan nilainilai religius di Fikom Unisba. Melihat fenomena yang terjadi di atas, maka Dekan Fikom Unisba sebagai pucuk pimpinan tertinggi di fakultas berusaha untuk menjawab tantangan tersebut. Penelitian ini mengkaji dua pokok persoalan dalam pertanyaan penelitiannya, antara lain: (1) Bagaimana strategi penguatan nilai-nilai religius sivitas akademika Fikom Unisba? (2) Mengapa strategi tersebut muncul sebagai penguatan nilai-nilai religius sivitas akademika Fikom Unisba?"

\section{METODE}

Penelitian ini terkait dengan upaya penguatan nilai religius yang dilakukan Fikom Unisba yang menggunakan pendekatan kualitatif. Pendekatan kualitatif sendiri bertujuan untuk menyediakan penjelasan tersirat mengenai struktur, tatanan, dan pola yang luas yang terdapat dalam suatu kelompok partisipan, dalam hal ini sivitas akademika Fikom Unisba. Pendekatan yang digunakan dalam penelitian ini 
adalah pendekatan studi kasus.

Studi kasus memungkinkan peneliti untuk mempertahankan karateristik holistik dan bermakna dari peristiwaperistiwa kehidupan. Definisi yang paling sering dijumpai tentang studi kasus, seperti yang diungkapkan oleh Scramm (dalam Yin, 2009:17):

"Esensi studi kasus,
kecenderungan utama dari
semua jenis studi kasus adalah
mencoba menjelaskan keputusan-
keputusan tentang mengapa
studi tersebut dipilih, bagaimana
mengimplementasikan dan apa
hasilnya".

Pemilihan metode studi kasus didasari oleh adanya kekhasan perilaku komunikasi yang dilakukan oleh suatu kelompok atau komunitas dengan latar belakang yang berbeda. Fikom sebagai satu dari 10 (sepuluh) fakultas yang ada di Unisba, tentunya memiliki keunikan tersendiri dalam melakukan penguatan nilai-nilai religius pada seluruh sivitas akademikanya.

Studi kasus adalah suatu desain penelitian yang berbentuk penjelasan tentang masalah, kejadian, atau situasi tertentu, kemudian mencari alternatif pemecahannya. Metode ini, dapat juga digunakan untuk mengembangkan cara berpikir kritis dan menemukan solusi baru dari suatu topik yang dipecahkan. Suatu inkuiri empiris yang menyelidiki fenomena di dalam konteks kehidupan nyata (Yin, 2013: 18 ).

Studi kasus dalam hal ini berusaha untuk menyelidiki fenomena di dalam konteks kehidupan nyata secara unik. Penelitian "Penguatan Nilai-Nilai Religius di Perguruan Tinggi" berusaha mengungkap secara mendalam mengenai penguatan nilai-nilai religius yang dilakukan sivitas akademika Fikom Unisba sesuai dengan tujuannya yang selalu berupaya untuk menghasilkan sumber daya manusia yang beriman, bertakwa, dan berakhlakul karimah sebagai mujahid, mujtahid, dan mujaddid. Penelitian ini menggunakan desain studi kasus tunggal.

Subjek dalam penelitiaan adalah Fikom Unisba, yakni sivitas akademika di lingkungan Fikom Unisba. Teknik yang digunakan dalam penentuan informan ini adalah sampling purposive. Sampling purposive adalah teknik penentuan sampel dengan pertimbangan tertentu dimana mengambil narasumber dengan pertimbangan narasumber yang mengetahui dan relevan dengan masalah yang ingin diketahui oleh peneliti (Sugiyono, 2013:34).

Berdasarkan Kriyantono (2007:154) maka kriteria informan dipertimbangkan agar dapat mendukung tujuan penelitian. Dengan pernyataan tersebut dan melihat masalah yang akan dibahas, yang menjadi subjek penelitian ini adalah O. Hasbiansyah selaku Dekan Fikom Unisba. Selain itu juga ada beberapa narasumber pelengkap penelitian yaitu dosen, tenaga pendidik, dan juga mahasiswa Fikom Unisba.

\section{Teknik Pengumpulan Data}

(1) Wawancara Mendalam.

Wawancara mendalam (dept interview) adalah teknik mengumpulkan data atau informasi dengan informan agar mendapatkan data lengkap dan mendalam. Wawancara ini dilakukan dengan frekuensi tinggi (berulang-ulang) secara intensif (Ardianto, 2010:178). Dalam hal ini wawancara dilakukan secara mendalam pada nara sumber penelitian.

(2) Observasi Lapangan.

Observasi lapangan atau pengamatan lapangan adalah kegiatan yang setiap saat dilakukan dengan kelengkapan panca indra yang dimiliki. Selain dengan membaca koran, 
mendengarkan radio, menonton televisi atau berbicara dengan orang lain, kegiatan observasi merupakan salah satu kegiatan untuk memahami lingkungan (Ardianto, 2010:179). Observasi lapangan ini dilakukan baik dalam kegiatan perkuliahan maupun kegiatan sehari-hari, interaksi antar sivitas, maupun observasi lingkungan fisik Fikom Unisba.

\section{(3) Dokumen.}

Dokumen merupakan catatan peristiwa yang sudah berlalu. Dokumen bisa berbentuk tulisan, gambar, atau karya-karya monumental dari seseorang. Dokumen yang berbentuk tulisan misalnya catatan harian, sejarah kehidupan (life stories), cerita, biografi, peraturan, kebijakan. Dokumen yang berbentuk gambar, misalnya foto, gambar hidup, sketsa dan lain-lain. Dokumen yang berbentuk karya misalnya karya seni, yang dapat berupa gambar, patung, film dan lain-lain. Studi dokumen merupakan pelengkap dari penggunaan metode observasi dan wawancara dalam penelitian kualitatif.

\section{Teknik Analisis Data}

(1) Pengumpulan data.

Penulis melakukan pengumpulan data melalui serangkaian data primer dan sekunder, di antaranya: (a) Data primer berupa data hasil wawancara peneliti dengan key informan.: (b) Data sekunder berupa laporan publikasi fakultas, data yang diperoleh dari fakultas Ilmu Komunikasi baik arsip maupun dokumen seperti memo;

(2) Reduksi data. Penulis melakukan reduksi data dengan cara wawancara, studi pustaka, dan juga observasi;

(3) Interpretasi data. Penulis melakukan interpretasi data didukung oleh tinjauan dengan menggunakan metode penelitian kualitatif, pendekatan studi kasus, dan paradigma konstruiktivis;

(4) Penarikan kesimpulan. Penulis melakukan penarikan kesimpulan berdasarkan data yang diperoleh di lapangan yang telah diolah dan interpretasi dari tinjauan teoritis.

Analisis Data yang dilakukan dalam penelitian ini adalah dengan mengumpulkan data melalui observasi yaitu terjun langsung ke lapangan atau terjun langsung ke kegiatan Fikom dan mewawancarai Dekan Fikom Unisba. Kemudian selanjutanya memproses data yang sudah didapatkan dan melakukan studi kepustakaan serta wawancara. Setelah itu disimpulkan penguatan nilainilai religius di Fikom Unisba.

\section{Keabsahan Data dan Hasil Penelitian}

Keabsahan data dari penelitian ini diperiksa secara ilmiah dengan Teknik Tringulasi. Tringulasi merupakan teknik pemeriksaan keabsahan data yang memanfaatkan sesutau yang lain di luar data untuk keperluan pengecekan atau sebagai pembanding terhadap data itu (Moleong, 2009:330).

Tringulasi yang digunakan dalam penelitian ini adalah tringulasi dengan sumber, yaitu berarti membandingkan dan mengecek balik derajat kepercayaan suatu informasi yang diperoleh (Moleong, 2009:330-331)

Untuk menguji keabsahan data yang diperoleh dalam penelitian, penulis melakukan observasi ke lapangan secara mendalam. Data dari hasil penelitian yang diperoleh melalui wawancara dengan para narasumber selanjutnya diuji keabsahan datanya dengan melakukan observasi langsung kepada beberapa dosen, tendik, dan mahasiswa di lingkungan Fikom Unisba. Penulis pun mengamati setiap aktivitas yang dilakukan oleh Fikom. Penulis akan mengamati dan menganalisis hasil wawancara dengan pendapat dosen, tendik, dan mahasiswa mengenai penguatan nilai-nilai religius di Fikom. 


\section{PEMBAHASAN \\ Potret Fikom Unisba}

Fikom Unisba atau lebih dikenal dengan sebutan Fikom Unisba diresmikan sebagai sebuah fakultas pada 7 Juni 1983 hingga saat ini, Fikom Unisba berhasil mempertahankan akreditasi unggul (A). Fikom Unisba dapat dikatakan sebagai perguruan tinggi swasta bidang komunikasi pertama di Jawa Barat, khususnya di Kota Bandung. Sama halnya dengan Unisba yang merupakan perguruan tinggi islam pertama di Kota Bandung.

Fikom merupakan salah satu jurusan yang difavoritkan di lingkungan Unisba. Visi yang diemban Fikom yakni menjadi fakultas unggul dalam pengembangan ilmu komunikasi berbasis teknologi dan nilai-nilai Islam. Demi terwujudkan visi tersebut, maka tujuan pendidikan Fikom sendiri diarahkan untuk menghasilkan insan komunikasi (sarjana Ilmu Komunikasi) yang memiliki pengetahuan dan kemampuan analisis, mampu berkerja sesuai dengan keahliannya, bersikap dan berperilaku sesuai etika profesi dan nilai Islam, serta mampu mengaktualkan seluruh kemampuannya dalam tata kehidupan di masyarakat.

Sebagaimana yang diungkapkan Rosyadi (2004:172), bahwa salah satu komponen penting dalam sistem kependidikan adalah pendidik. Melalui pendidik inilah para peserta didik diantarkan, dibimbing dan diarahkan pada tujuan yang telah ditentukan.

Fikom Unisba senantiasa berupaya untuk menstransformasikan nilai-nilai secara konsetual, kontekstual, dan situasional. Dosen sebagai kelompok yang terlibat langsung dan bertanggung jawab di perguruan tinggi. Konsep dasar yang diemban oleh perguruan tinggi yakni memelihara dan mengembangkan kehidupan akademik. Fikom Unisba sebagai salah satu perguruan tinggi swasta yang bernafaskan Islam, bertanggung jab atas penyuburan kegiatan dan perkenalan karya yang mengandung nilai-nilai akademiknya. Salah satunya diterjemahkan melalui komposisi mata kuliah keislaman. Bobot pendidikan agama dalam kulikulumnya tersusun apik dari mulai semester awal hingga akhir, termasuk di dalamnya kegiatan pesantren mahasiswa baru dan pesantren calon sarjana. Karena Fikom Unisba menyakini betul bahwa ilmu adalah kekuatan. Knowledge is power.

\section{Nilai Religius}

Dilihat dari bahasannya, nilai religius berasal dari gabungan dua kata, yakni kata nilai dan kata religius. Kata nilai menurut Badudu (1996:944) dapat diartikan secara etimologis yakni harga, derajat. Dan kata religius. Nilai juga menurut Mulyana (2004:9) sebagai konsepsi (tersirat dan tersurat, yang sifatnya membedakan individu atau ciriciri kelompok) dari apa yang diinginkan, yang mempengaruhi pilihan cara, tujuan, antara dan tujuan akhir tindakan. Sedangkan kata religius biasa diartikan dengan kata agama, namun juga bisa diartikan sebagai keberagamaan. Agama tersusun dari dua kata, $a$ artinya tidak dan gama artinya pergi, jadi agama artinya tidak pergi, tetap di tempat, diwarisi secara turun temurun. Agama dikatakan sebagai sistem kepercayaan yang tidak stagnan dan terus berkembang sesuai dengan tingkat kognisi (pengetahuan) seseorang.

Thontowi (2012) mengemukakan bahwa kata dasar dari religius adalah religi yang berasal dari bahasa asing religion sebagai bentuk dari kata benda yang berarti agama atau kepercayaan akan adanya sesuatu kekuatan kodrati di atas manusia. Sedangkan religius berasal dari kata religious yang berarti sifat religi yang melekat pada diri seseorang.

Nilai religius perlu ditanamkan dalam lembaga kependidikan, dalam hal 
ini Fakultas Ilmu Komunikasi Universitas Islam Bandung untuk membentuk kepribadian muslim yang mantap dan kuat di lembaga pendidikan tersebut. Di samping itu, sebagaimana dikemukakan Rifa'i (2016) penanaman nilai religius penting dalam rangka memantapkan etos kerja dan etos ilmiah seluruh sivitas akademika, agar tertanam dalam diri tenaga kependidikan bahwa melakukan kegiatan pendidikan dan pembelajaran merupakan bagian dari ibadah.

Nilai-nilai religius diterapkan Unisba dalam kurikulum yang diemban di setiap fakultasnya. Diketahui bersama bahwa tujuan kurikulum adalah menciptakan conceptual mastery, di mana para mahasiswa dituntut untuk menguasi konsep-konsep dasar yang telah dituangkan di dalam visi misi universitas dan visi misi fakultas. Seluruh fakultas dibekali dengan mata kuliah Pendidikan Agama Islam sebanyak VII (tujuh) semester. Yakni Pendidikan Agama Islam dari semester I (satu) hingga semester IV (enam), dengan rincian sebagai berikut: PAI I Aqidah, PAI II Pesantren, PAI III Fiqih, PAI IV Akhlak, PAI V Sejarah Islam, PAI VI Peradaban Islam, dan PAI VII Islam Disiplin Ilmu. Hal tersebut didukung oleh pernyataan Chapman (2011) dalam Implementing Character Education into School Curriculum. Hal yang sam juga dikemukakan oleh Elias (2010), yang menyatakan bahwa pendidikan dilakukan dalam seluruh setting kegiatan pembelajaran yang baik. Dengan membekali kurikulum nilai-nilai religius selama VII (tujuh) semester, diharapkan mahasiswa dapat menjaga nilai-nilai religius sebagai kekhasan yang dimiliki Unisba.

\section{Nilai-Nilai Religius Unisba Dosen dan Tendik}

(1) Seleksi Awal
(a)
Tes BTAQ
(b) Tes Pengetahuan Umum

\section{Keislaman}

(2) Prajabatan selama 1 minggu di Kampus II Unisba, Ciburial

(3) Pengajian Umum yang digagas oleh Lembaga Studi Islam dan Pengembangan Kepribadian (LSIPK) Unisba di Masjid AlAsy'ari, dengan penceramah yang berasal dari internal Unisba serta tema disesuaikan dengan bidang keilmuan masing-masing.

Dapat dilihat bahwa proses menjaringan dosen dan tenaga kependidikan sedari hulu mendapat terpaan yang kuat dengan nilainilai keislaman. Kemudian di dalam prosesnya (setelah terjaring) dosen dan tenaga kependidikan terus mendapatkan membinaan baik dari rektorat, yayasan, universitas, maupun fakultas, bergantung pada penempatannya. Mahasiswa saat ini, berani berfikir lebih objektif, kritis, dialogis, dan argumentatif, sehingga dosen dalam hal ini berperan bukan hanya menjadi sumber, melainkan sebagai fasilitator belajar. Implikasinya, dosen senantiasa didorong untuk terus meningktakan kemampuan dan kompetansi diri.

\section{Mahasiswa}

\section{(1) Seleksi Awal}

\section{(a) Tes BTAQ}

(b) Tes Pengetahuan Umum Keislaman

(2) Mata kuliah Pendidikan Agama Islam di setiap semester. Dari aqidah hingga disiplin ilmu.

(3) Pesantren sebanyak 2 kali, yakni pesantren mahasiswa baru di semester II, dan pesantren calon sarjana. Dilaksanakan di Kampus II Unisba, Ciburial

(4) BTAQ untuk mahasiswa baru yang diselenggrakan oleh BOMPAI Unisba

Proses belajar yang dilakukan oleh mahasiswa, dosen, dan tenaga 
kependidikan dilakukan untuk pendewasaan kepribadian serta mempertahankan nilai-nilai rujukan, yang nantinya bermuara pada pemberdayaan diri, kelompok, atau organisasi. Sehingga dalam hal ini, diperlukan suatu proses belajar yang bermakna. Diawali dengan proses penerimaan mahasiswa yang diseleksi, mata kuliah Pendidikan Agama Islam di tiap semester, pesantren calon mahasiswa dan calon sarjana, sehingga penguatan nilai-nilai keislaman dibina dari proses input dan outputnya,

\section{Nilai-Nilai Religius Khas Fakultas Ilmu Komunikasi Unisba \\ Dosen dan Tendik}

(1) Pengajian secara berkeliling, silaturahim mengunjungi rumahrumah dosen dan tendik.

(2) Memulai pekerjaan dengan membaca Al-Quran setiap pagi sebelum memulai aktivitas. Diharapkan membuat pekerjaan lebih optimal dan dirahmati (AlIsra-82). Dalam hal ini, narasumber berpendapat bahwa membaca Al-Quran di awal pekerjaan sangat bagus dan dapat membawa ketenangan hati untuk para dosen dan tendik yang mengikutinya. Ini juga terinspirasi dari Fakultas Ekomuni yang ada di lingkungan Universitas Islam Bandung, yang membiasakan untuk membaca asmaul husna sebelum rapat.

(3) Imbauan dekan untuk melaksanakan solat berjamaah di masjid. Memakmurkan masjid (QS At-Taubah:17). HR Muslim (653) seandainya solat berjamaah boleh dilakukan di mana saja, tentu Rasulullah saw member izin kepada lekaki buta untuk solat di rumahnya secara berjamaah bersama keluarganya. Begitu pentingnya pergi ke mesjid untuk solat berjamaah, sehingga orang yang buta saja tidak diberi keringanan (Al-Ausath)(4/134)

(4) Mendisiplinkan diri dengan ketentuan pakaian yang diterapkan, agar bisa menegakkan aturan bagi mahasiswa yang melanggar. Bagi dosen, bisa memerintahkan mahasiswanya keluar dari kelas; bagi tendik, bisa melakukan pembiaran (tidak memperoleh pelayanan akademik dan administrasi di lingkungan Fikom Unisba.

(5) Kunjungan penelitian dan pengabdian kepada masyarakat ke pesantren-pesantren. 9-10 November 2017 Fakultas Ilmu Komunikasi, dosen beserta tendik, dan laboran berkesempatan untuk melaksankan PKM di Pondok Pesantren Al-Ikhlash, Ciawigebang-Kuningan.

(6) Implementasi nilai-nilai religius pada saat perkuliahan.

Penyisipan nilai-nilai religius juga dapat dilakukan untuk setiap mata kuliah, bergantung kepada dosen. Beberapa dosen telah berupaya untuk mengaitkan bahasan perkuliahannya dengan ayatayat Quran yang mendukung. Sebagai contoh, untuk memotivasi mahasiswa agar senantiasa menggali ilmu, dosen membuka perkuliahannya dengan surat Al Mujaadilah:11. Beberapa dosen Fikom juga memasukan etika dalam persentasi penilaiannya. Sehingga perolehan nilai tidak hanya didapat dari hasil ujian tengah dan akhir semester, makalah, presentasi dan tugas saja, tetapi juga dari etika yang diperlihatkan mahasiswa selama menjalankan perkuliahan di kelas sebanyak 14 kali pertemuan. Hal ini menjadi tantangan bagi para dosen untuk senantiasa melakukan penguatan kepada peserta didiknya (mahasiswa). Keragaman yang dimunculkan oleh setiap dosen, menjadi ciri khas bagi dosen tersebut yang nantinya akan mendorong 
kepada penguatan.

Mengutip dari penelitian terkait Perilaku Bermedia Digital dalam Pelaksanaan Tridharma Perguruan Tinggi di kalangan Dosen Unisba, Dian Widya Putri, dkk (2017:23) menyatakan bahwa: ... Dosen Unisba mulai menunjukkan tren menggunakan media digital pada perkuliahan, mencari referensi ilmiah dan publikasi hasil penelitiannya serta PKM meski masih secara terbatas pada media yang dirasa umum dan mudah diguankan."

Nilai-nilai religius khas Fakultas Ilmu Komunikasi Unisba yang diimplemtasikan melalui dosen dan tendik diharapkan dapat menguatkan nilai-nilai religius. dosen dan tentik sebagai agen sosialisasi utama dan pertama bagi para mahasiswanya.

\section{Mahasiswa}

(1) BTAQ sebelum sidang komprehensi dan skripsi. Di bawah bimbingan dosen dan tendik Fikom Unisba untuk lebih memantapkan lagi calon sarjananya;

(2) Ketentuan pakaian sesuai SK Dekan Fikom No.002/SK/DekFIK/X/2010.

(a) Mahasiswi tidak diperkenakan menggunakan kaos oblong, bajulengan pendek/minim/di atas sikut, baju/celana ketat, pakaian transparan, pakaian yang memperlihatkan dada, punggung, bokong, pusar, pinggang terbuka, pakaian bergambar/bertulisan tidak sopan, bertentangan dengan nilai-nilai Islam dan nilai kesusilaan, celana sobek, celan pendek, rok mini/ di atas lutut, bertato pada bagian tubuh yang terbukal terlihat, gaya rambur punk mencolok, mengenakan sandal. Yang diperkenankan: pakaian muslimah. Mahasiswa: T-Shirt, kaos berkerah, kemeja tangan pendek/panjang, baju koko, jaket, baju jas.; (b) Khusus hari Jumat: Mahasiswi: mengenakan pakaian muslimah (berkerudung) atau memakai baju batik dan berkerudung. Mahasiswa: mengenakan baju batik atau mengenakan baju koko (tangan pendek atau panjang).; (c) Ketentuan tsb. tertuang dalam buku pedoman akademik yang dimiliki Fakultas Ilmu Komunikasi Universitas Islam Bandung, yang dibagikan pada saat taaruffakultas dilaksanakan.

Ketentuan tersebut tertuang khusus di dalam buku pedoman akademi Fakultas Ilmu Komunikasi Universitas Islam Bandung, dan dibagikan kepada setiap mahasiswa barunya di awal acara perkenalan (taaruf) fakultas;

(3) Mahasiswa didorong menjadikan Quran dan hadist sebagai rujukan dalam pembuatan makalah dan presentasinya, bukan hanya sumber yang berasal darijurnal dan buku. Ini dilakukan dalam upaya penguatan Al-Quran sebagai sumber ilmu pengetahuan yang tidak pernah mati. Pada masa berkembangnya Islam dulu, banyak pakar muslim yang menjadi orang hebat karena selalu berpegang teguh pada AlQuran.

Penguatan tersebut dilakukan secara bertahap dan melalui sosialisasi, tercacat dekan fakultas melakukan sosialisasi selama satu tahun sebelum ketentuan diberlakukan, sehingga muncul pemahaman dan pembiasaan yang terintegrasi dengan kegiatan yang telah 
diprogramkan.

\section{Lingkungan (Setting)}

Lingkungan pendidikan dapat menumbuhkan budaya keagamaan, sehingga mampu menciptakan generasigenerasi yang berkualitas dan berkarakter baik dan kuat sebagai pelaku utama kehidupan di masyarakat. Suasana lingkungan dapat membimbing peserta didik agar mampu mempunyai akhlak mulia, perilaku jujur, disiplin, dan semangat untuk ,meningkatkan kualitas diri.

Situasi keagamaan di Fakultas Ilmu Komunikasi Unisba sendiri sudah dibangun dengan kondisi lingkungan yang agamis, ini terlihat dengan adanya peralatan peribadatan seperti masjid dan mushalla, alat-alat solat seperti sarung, peci, mukena, sajadah, Al-Qur'an, ornamen keislaman seperti kaligrafi. Di samping itu, dalam membahas suatu materi pelajaran selalu diperkuat oleh nash-nash keagamaan yang berlandaskan Al-Qur'an dan hadist Rasulullah saw.

\section{SIMPULAN}

Fakultas Ilmu Komunikasi Universitas Islam Bandung bukanlah ruang hampa makna. Pengauatan nilainilai religius mutlak ditanamkan di setiap lini kehidupannya. Mulai dari kurikulum, sumber daya manusia (tenaga pendidik, tenaga kependidikan, dan mahasiswa), maupun lingkungan kerja (setting). Banyak hal yang dapat dilakukan untuk merealisasikan pendidikan karakter di lingkungan perguruan tinggi yang bernafaskan Islam. . Fakultas Ilmu Komunikasi Universitas Islam Bandung sendiri menjadikan pendidikan karakter sebagai sebuah tatanan nilai yang berkembang dengan baik, yang diwujudkan secara nyata dalam keseharian guna mendukung terwujudnya visi, misi, serta tujuan Fikom Unisba, yakni menjadi fakultas unggul dalam pengembangan
Ilmu Komunikasi berbasis teknologi dan nilai-nilai Islam.

\section{DAFTAR PUSTAKA}

Agustian, Ary G. (2008). Peran ESQ dalam Peningkatan Kualitas Pendidikan. Pidato dies natalis ke44 Universitas Negeri Yogyakarta, 21 Mei 2008. Yogyakarta: UNY Press.

Ardianto, Elvinaro. (2010). Metode Penelitian Untuk Public Relatios Kuantitatif Dan Kualitatif. Bandung: Simbiosa Rekatama Media.

Badudu, J. S \& Zain SultanMohammad. (1996). Kamus Umum Bahasa Indonesia. Jakarta: Pustaka Sinar Harapan.

Chapman, Alicia M. (2011). Implementing Character Education into School Curriculum, http:// dc.cod.edu/cgi/viewcontent. cgi article $=1355 \&$ context $=$ essai, diunduh pada 25 Juli 2018.

Daulay, Haidar Putra. (2012). Pendidikan Islam dalam Sistem Pendidikan Nasional di Indonesia. Jakarta: Kencana

Elias, Maurice, Ed. (2010). Character Education: Better Students, Better People. Education Digest: Essential Readings Condensed for Quick Review, vol 75 no 7 page 47-49 Mar 2010

Gray, Tiffany. 2010. Character Education in Schools. http:// dc.cod.edu/cgi/viewcontent. cgi article $=1116 \&$ context $=$ essai, diunduh pada 25 Juli 2018.

Kriyantono, Rachmat. (2010). Tekhnik Praktis Riset Komunikasi: disertai contoh praktis riset media, public relations, advertising, komunikasi organisasi, komunikasi pemasaran . Jakarta : Kencana

Moleong, Lexy. (2009). Metode Penelitian Kualitatif. Bandung : 
PT. Remaja Rosda Karya

Mulyana, Rohmat. (2004). Mengartikulasikan Pendidikan Nilai. Bandung: Alfabeta.

Putri, Dian Widya dkk. (2017). Perilaku Bermedia Digital dalam Pelaksanaan Tridharma Perguruan Tinggi di kalangan Dosen Unisba. MediaTor, Vol 10 (1), Juni 2017, 11-24.

Rosyadi, Khoiron. (2004). Pendidikan Profetik. Yogyakarta: Pustaka
Pelajar.

Sugiyono. (2013). Metode Penelitian Kuantitatif, Kualitatif dan $R \& D$. Bandung: CV. Alfabeta.

Thontowi, A. (2012). Hakekat Religiusitas. (Online), http://www. sumsel.kemenag.go.id, diunduh pada 25 Juli 2018

Yin, Robert. K. (2013). Studi Kasus; Desain dan Metode. Jakarta: Raja Grafindo Persada. 